\title{
The Development of Students' Intrapersonal Instrument of Electrical Engineering Program Vocational Schools in Bali
}

\author{
I Gede Ratnaya \\ Electrical Engineering \\ Ganesha University of Education \\ Singaraja, Indonesia \\ Gede.ratnaya@undiksha.ac.id
}

\author{
Gaguk Margono \\ Mechanica Engineering \\ Universitas Negeri Jakarta \\ Jakarta, Indonesia \\ g_margono@yahoo.com
}

\begin{abstract}
This research aimed to develop an instrument to measure the intrapersonal skill of Electrical Engineering Program students at Vocational High School in Bali by using Likert scale. This capability is important in regulating and monitoring personal's goals during vocational education at SMK. This instrument has been tested to 110 students at Engineering Utilization of Electricity Program in the entire province of Bali. The validation of the instrument through the content validation by the experts, the validation grains measure with Momment Product engineering, and the validation of the construct done by factor analysis. Factor analysis uses the confirmation method Maximum Likelihood (ML) with the conformity or suitability obtained Chi Square amounted to 113,8 (p-value $=0,2622)$ and Goodness of Fit Index (GFI) by 0.92
\end{abstract}

Keywords - intrapersonal intelligence, vocational students, factor analysis

\section{INTRODUCTION}

Nowadays the growth of education is shifted to students' progress in several domains that include the cognitive domain, the psychomotor domain, and the affective domain $[1,3,5,11$, 13, and 18]. These three domains are measured through different instruments. In general, cognitive abilities are measured through test instruments [4], psychomotor abilities are measured through observation sheets, and affective abilities are measured through questionnaires. In the assessment of students' abilities, the instruments heed to be reliable. According to Naga [14], measurements in education include several things. First to measure the hidden features that was invisible of the participants / students. Second, to measure the latent characteristics of the students was by giving a stimulus in the form of a questionnaire or a precise measuring instrument. Third, the responses can reflect the underlying features of the students. Fourth, the responses gained can be adequately scored and interpreted. To meet the above four things, the instrument must have the process of validation before it is used. According to Djaali [6], there are several kinds of validity, namely content validity, construct validity, and empirical validity or validity criteria. The content validity is used to measure the degree of mastering content of a particular material that should be mastered in accordance with the learning objectives. In accordance with Gregory [10], to know the instrument is valid or not, it must be done through the examination of the test / instrument grid to ensure that the items represent or reflect the overall content or material that should be proportionally controlled. Therefore, Wiersma and Jurs [20] state that content validity is basically based on logical analysis, so it is not a statistically calculated coefficient of validity. Furthermore, Mardapi [16] writes that the evidence of validity is determined according to a rational analysis of the content of the test / instrument whose judgment is based on individual subjective judgment. According to Azwar [2], the logic decision on the alignment of grains with the purpose of measuring (indicator) cannot be based on the author his/her self only but also it requires an assessment agreement from some competent assessors in that field. The validity of the instrument applies not only to cognitive and psychometrics instruments but also to affective instruments.

Intrapersonal Ability is the ability of oneself. This ability is the ability to understand oneself and be responsible for one's own life. Intrapersonal ability is one form of personal ability; the other is the interpersonal skills according to Gardner [9]. Lwin reveals that children with high intrapersonal skills tend to think of self-assessment. Such of these children like to do self-introspection, correct the shortcomings and weaknesses, then try to improve themselves [17]. According to Hoerr [12], students' activities that reflect intrapersonal skills are controlling feelings and moods [7], pursuing personal interests and organizing self-agenda, learning through observation and listening, and using meta-cognitive skills.

Thus, this research was focused on the preparation and development of students' intrapersonal instrument of SMK Electrical Engineering Program in Bali with research problems such as, first, how are the compilation stages of students' intrapersonal instrument. Second, how the students' intrapersonal instrument met the principles of construct validity in theory and empirical. Third, how the reliability of the instrument.

\section{II.RESEARCH METHODS}

The research was conducted at all SMK Electrical Engineering Program in Bali. The population was the students of SMK Electrical Engineering Program. The sample of the study was done by random sampling technique on Electrical 
Engineering Program. The data were collected with questionnaires.
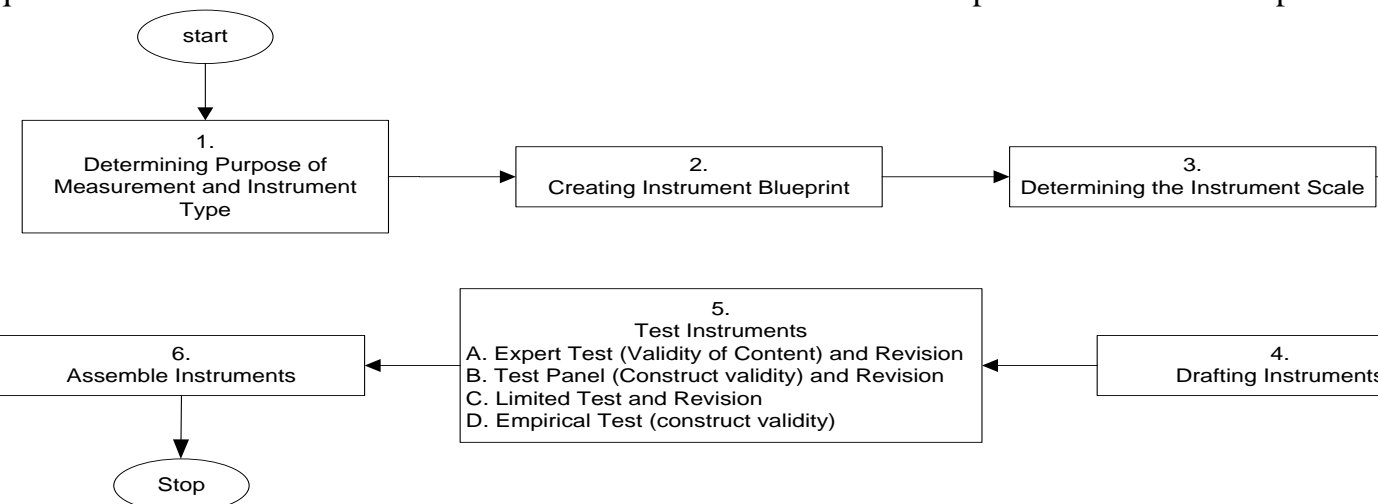
Test Instruments
A. Expert Test (Validity of Content) and Revision
B. Test Panel (Construct validity) and Revision D. Empirical Test (construct validity)

Figure 1. Stages of Instrument Development

The instrument was a questionnaire by using Likert-scale model. According to Mardapi [16], the Likert scale is commonly used in the measurement of the affective domain. According to Suryabrata [19], this method is actually called summated ratings but since it was first proposed by Rensis Likert in 1932 then this scale is famous by the scale of Likert model. The draft of the instrument was arranged in accordance with the instrument's blueprint and the structure of the relationship between the specified instrument and indicator items.

On the instrument testing stage, there were four times tests. Expert test was conducted by asking the opinion of 3 experts who are competent in the field of Counseling Guidance, Research and Evaluation of Education, and a senior vocational teacher. Content validity was measured by Gregory [10] formula:

$$
V I=\frac{H}{A+B+C+D+E+F+G+H} 100 \%
$$

Note:

A: Cell that shows the disagreement of the three experts

B: Cells that show expert 1, 3 disagree and expert 2 agree / relevant

C: Cells showing expert 2, 3 disagree and expert 1 agree / relevant

D: Cells that show expert 3 disagree and expert 1, 2 agree / relevant

E: Cells that show expert 1, 2 disagree and expert 3 agree / relevant

F: Cells shows expert 1 disagree and expert 2, 3 agree / relevant

G: Cells that shows expert 2 disagree and expert 1, 3 agree / relevant

$\mathrm{H}$ : That cell indicating a valid agreement by all three experts.

Furthermore, a panelist test was conducted to measure the validity construct by asking for opinions and suggestions from 20 doctoral students of Educational Research and Evaluation who are preparing a dissertation. The validity of the constructs is measured by applying the Lawshe method as follow.

$$
C V R=\frac{2 N e}{N}-1
$$
important, $\mathrm{N}=$ Number of panelists grains with the following formula. tested for respondents $\mathrm{j}$, ( $\alpha$ ) formula. item of $\mathrm{i}$ for respondent to $\mathrm{j}$
The development of the instrument uses an approach to response with the development stage as shown in Figure 1.

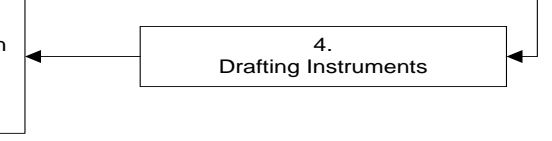

Note: $\mathrm{Ne}=$ Number of panelists who state important or very

A limited test was conducted on 10 vocational students to examine the items of the instrument, whether the statement could be understood or not. Empirical test was conducted on the students of SMK electrical engineering program in Bali. The data of empirical test was processed by Product Moment correlation formula $(\alpha)$ to know the internal validity of

$$
r_{x_{i}}=\frac{N \sum_{j=1}^{N} X_{i j} Y_{j}-\left(\sum_{j=1}^{N} X_{i j}\right)\left(\sum_{j=1}^{N} Y_{j}\right)}{\sqrt{\left(N \sum_{j=1}^{N} X_{i j}{ }^{2}-\left(\sum_{j=1}^{N} X_{i j}\right)^{2}\right)\left(N \sum_{j=1}^{N} Y_{j}{ }^{2}-\left(\sum_{j=1}^{N} Y_{j}\right)^{2}\right)}}
$$

Note: $\mathrm{N}=$ Number of respondents, $\mathrm{Xij}=$ Scores of items of $\mathrm{i}$

$$
\mathrm{Yj}=\text { Total score of respondents } \mathrm{j}
$$

The items that have under $r$ ttabel are declared unfeasible to be put on the instrument. Furthermore the reliability of the instrument was calculated by the following Cronbach Alpha

$$
\begin{gathered}
\alpha=\left(\frac{N}{N-1}\right)\left(\frac{S^{2}-\sum S i^{2}}{S^{2}}\right) ; \\
S i^{2}=\frac{k \sum X_{i_{j}}{ }^{2}-\left(\sum X_{i j}\right)^{2}}{k(k-1)}
\end{gathered}
$$

Note: $\quad N=$ Number of items, $S_{i}{ }^{2}=$ Variant item of i, $S^{2}=$ Total score variant, $k=$ Number of respondents, $X_{i}=$ Score

The Construct Reliability (CR) can be calculated based on the standardized loading factor (SLF) and Standardized Error Variance (SEV) with the following formula. 


$$
C R=\frac{\left(\sum S L F\right)^{2}}{\left(\sum S L F\right)^{2}+\sum S E V}
$$

\section{III.RESULTS AND DISCUSSIONS}

There were 9 indicators that have been identified and there were 44 statements. Based on the result of the content validity test that was conducted by 3 experts, 3 items were declared unfit to be put on the instrument because the items were considered by experts to have double meaning so that they cannot be used to represent one indicator. Thus VI $=93 \%$. Based on the theoretical construct test, that was conducted through the panel discussion, there are 3 items that must be out because the respondent will not understand with the statement, the three items had CVR coefficient smaller than 0.2. So until the panelist test, there were 6 items that are not suitable to measure the intrapersonal ability of the students.

Furthermore, empirical test was conducted to 110 students of SMK Electrical Engineering Program. The data was inputted through SPSS Statistics 22 software. There were 38 items analyzed its validity based on Product Moment correlation formula. With $\mathrm{N}=110$ and the significance level $\alpha$
$=0.05$ with the 2-tailed test system, the result states that there are 6 items not feasible because p-value of significance are above 0.05 or the coefficient below $0.17(\mathrm{r}-$ table $=0.19)$.

Reaching on this stage, there were 32 items those were ready to be analyzed by confirmatory factor analysis. For this analysis, it used lisrel software 8.70. Through this analysis, it can be freely determined that the model of constructs that fit the theory. In this analysis there were some minimum requirements that must be fulfilled by the constructed model chosen to be stated that the item is valid construct, which the factor load has a t-count value more than 1.96 and the p-value of Chi Square is more than 0.05 to declare the chosen construct model in accordance with observational data (empirical data). The first stage, the 32 items were analyzed and the results were in accordance to Figure 2. The symbol of The INTRA_1 to INTRA_9 is an indicator 1 through indicator 9. The model consisted of 32 items, and then there were only 18 items that were constructed to obtain p-value Chi Square more than 0.05 which is 0.08067 according to figure 2 and the $\mathrm{t}$-count factor was more than 1.96 in accordance with the figure 3 . The items have been in accordance with the theory construct.
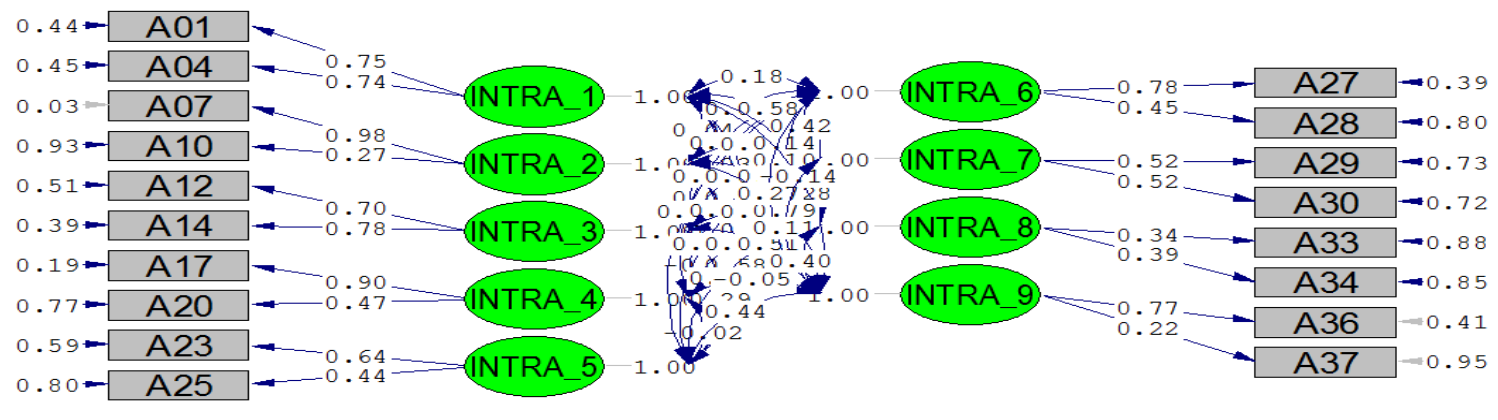

Chi-Square=122.59, df=102, $\mathrm{P}-\mathrm{value}=0.08067, \mathrm{RMSEA}=0.043$

Figure 2. Constructed model of 18 Items and standardized factor loads
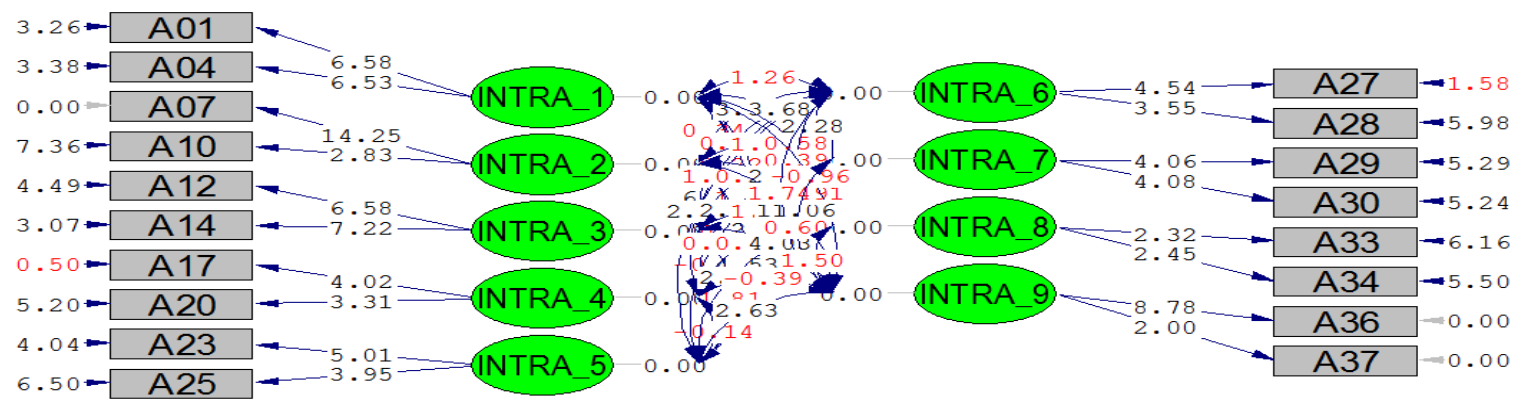

Chi-Square=122.59, df=102, P-value=0.08067, RMSEA=0.043

Figure 3. The construct model 18 items and t-count the factor load on an instrument consisting of 32 items

Furthermore, the researchers assembled the 18 items in to an instrument and tested to 134 students of SMK Electrical
Engineering Program. Each indicator consisted of 2 items. The result of the process was obtained by the construct again as shown in Figure 4 and Figure 5. 


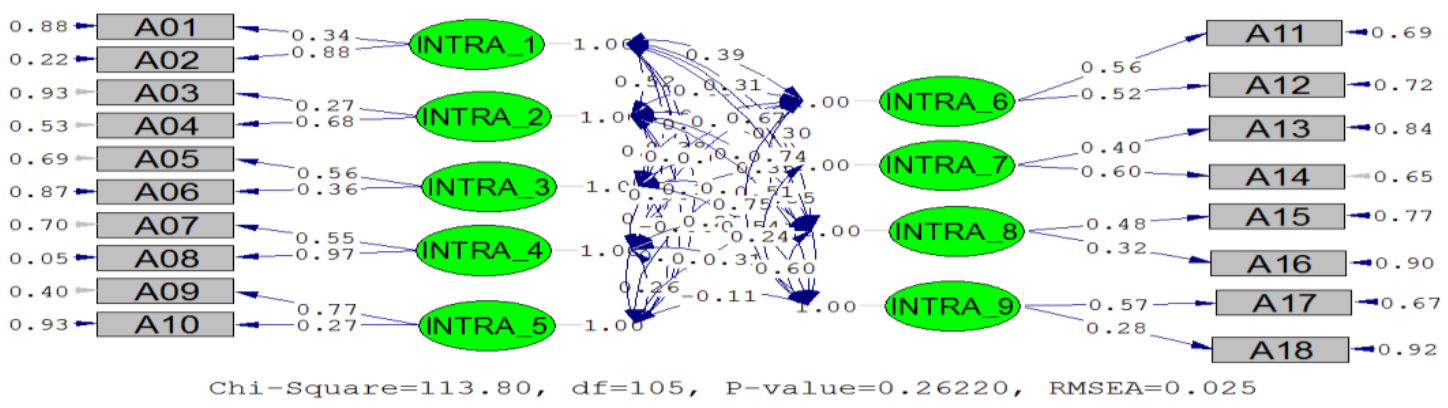

Figure 4. 18 items construction models and standardized factor loads on instruments that consists of 18 items.

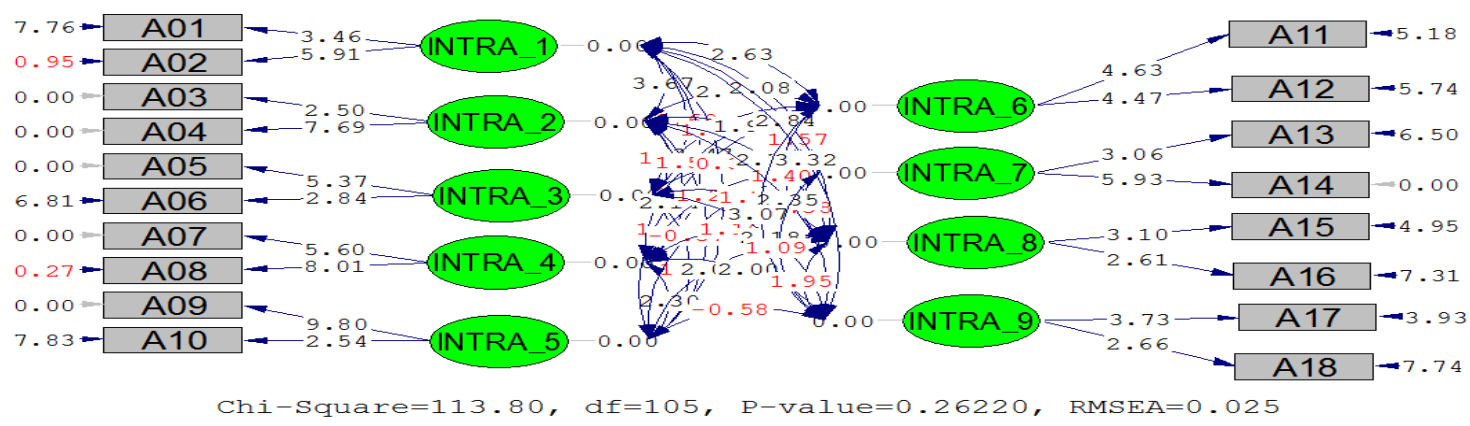

Figure 5. The 18 items construction model and the t-count factor load on an instrument consisting of 18 items

By selecting the 18 items construct model in an instrument which consisted of 2 items of each according to figure 2, yields Chi Square $=113.8$ with $\mathrm{p}$-value Chi Square $=$ $0.26220>0.05$, t-count The item factor loads were all more than 1.96 and the Goodness of Fit Index (GFI) $=0.92>0.9$. Thus the chosen construct was in accordance with the observed data (empirical), so that the items were declared as valid items for construct. According to Figures 4 and 5, the items were selected according to the table 1.

TABLE 1. THE ELIGIBLE ITEMS REPRESENTS INDICATORS

\begin{tabular}{clc}
\hline Symbols & \multicolumn{1}{c}{ Indicators } & $\begin{array}{c}\text { No. Item } \\
\text { represents }\end{array}$ \\
\hline INTRA_1 & $\begin{array}{l}\text { Emotional stability (self- } \\
\text { conscious) }\end{array}$ & 1,3 \\
\hline INTRA_2 & $\begin{array}{l}\text { Be able to organize and } \\
\text { motivate own self }\end{array}$ & 5,8 \\
\hline INTRA_3 & Responsible for own self & 10,12 \\
\hline INTRA_4 & Self development & 13,16 \\
\hline INTRA_5 & Build self-esteem & 19,21 \\
\hline INTRA_6 & $\begin{array}{l}\text { Know the strengths and } \\
\text { weaknesses of own self }\end{array}$ & 23,24 \\
\hline INTRA_7 & Reflective thinking & 25,26 \\
\hline INTRA_8 & $\begin{array}{l}\text { Express self-fulfillment } \\
\text { appropriately }\end{array}$ & 28,29 \\
\hline
\end{tabular}

INTRA_9 $\quad$ Self confidence $\quad 31,32$
The key analysis in this study was Confirmatory Factor Analysis. This analysis used Maximum Likelihood estimation. Maximum Likelihood Estimation on Confirmatory Factor Analysis provides more alternatives for choosing the construct model. The construct model consisted of 18 points above was one of the alternatives. There are still other alternatives to choose that provide different levels of compatibility. The reliability coefficient in this study has a value lower than the attitude coefficient reliability that developed by Margono which is 0.710 [8] but, the difference in value was not conspicuous.

\section{IV.CONCLUSION AND SUGGESTIONS}

The instrument developed was in the form of questionnaires that used the Likert measurement scale. Based on the results of all 44 item pre test, as the original amount, this study standardized 18 items as an instrument of students' intrapersonal instrument. The instrument consisted of 9 indicators (each item represents 2 indicators). The instrument measured the affective domain. For a further suggestion to students, this kind of instrument can be meticulous and develop by using different measurement scales.

\section{REFERENCES}

Anderson, L. W. and Krathwohl, D. R., et al (Eds.) (2000) A Taxonomy for Learning, Teaching, and Assessing: A Revision of Bloom's Taxonomy of Educational Objectives (complete edition) . Allyn \& Bacon. Boston, MA (Pearson Education Group).

[2] Azwar, Saifuddin. (2015). Penyusunan Skala Psikologi. Yogyakarta: Pustaka Pelajar. 
[3] Bloom, B.S. and Krathwohl, D. R., et al.(1956) Taxonomy of Educational Objectives: The Classification of Educational Goals,by a committee of college and university examiners. Handbook I: Cognitive Domain. NY, NY: Longmans, Green (This is the original work. It is unavailable for purchase, however there are later editions available.)

[4] Choi, Jean, Shaila Sardar (2011). "An Empirical Investigation of the Relationships Among Cognitive Abilities, Cognitive Style, and Learning Preferences in Students Enrolled in Specialized Degree Courses at a Canadian College," The Canadian Journal for the Scholarship of Teaching and Learning: Vol. 2 : Iss. 1 , Article 5. DOI: http://dx.doi.org/10.5206/cjsotl-rcacea.2011.1.5

[5] Dave, R.H. (1970). Psychomotor levels in Developing and Writing Behavioral Objectives. R.J. Armstrong, ed. Tucson, Arizona: Educational Innovators Press. (Unavailable for purchase)

[6] Djaali, H., Muljono, Pudji (2008). Pengukuran Dalam Bidang Pendidikan. Jakarta: PT Grasindo.

[7] Fletcher, Garth J. O. and Margaret S (2003). Clark. Blackwell Handbook of Social Psychology: Interpersonal Processes, ed. Melbourne: Blackwell Publishers Ltd.

[8] Margono, Gaguk (2014). "Pengembangan Instrumen Sikap Terhadap Statistika Menggunakan Skala Diferensial Semantik." Prosiding Seminar Nasional Psikometri.

[9] Gardner, Howard. (2011). Frames of Mind: The Theory of Multiple Intelligences. New York: Howard Gardner.

[10] Gregory, Robert J. (2000). Psychological Testing: History, Principles and Applications. Boston: Allyn and Bacon.

[11] Harrow, A. (1972) A Taxonomy of Psychomotor Domain: A Guide for Developing Behavioral Objectives. New York: David McKay.

[12] Hoerr, Thomas R. (2000). Becoming a multiple intelligences school. Alexandria: Association for Supervision and Curriculum Development.

[13] Krathwohl, D.R., Bloom, B.S., Masia, B.B. (1964). Taxonomy of Educational Objectives, the Classification of Educational Goals. Handbook II: Affective Domain. New York: David McKay Co., Inc.

[14] Naga, D. S. (1992). Pengantar Teori Sekor Pada Pengukuran Pendidikan. Jakarta: Gunadarma.

[15] _ Teori Sekor Pada Pengukuran Mental. Jakarta: PT Nagarani Citrayasa.

[16] Mardapi, Djemari (2012). Pengukuran dan Penilaian \& Evaluasi Pendidikan. Yogyakarta: Nuha Medika.

[17] May Lwin et al., Cara Mengembangkan Berbagai Komponen Kecerdasan terjemahan Christine Sujana (Jakarta : PT Indeks, 2008),

[18] Simpson E.J. (1972). The Classification of Educational Objectives in the Psychomotor Domain. Washington, DC: Gryphon House.

[19] Suryabrata, Sumadi (2005). Pengembangan Alat Ukur Psikologis. Yogyakarta: Andi Offset

[20] Wiersma, William and Stephen G. Jurs. (1990). Education Measurement and Testing. Boston: Allyn and Bacon. 